\title{
The "Honorable" Gentlemen in Hard Times
}

\author{
Mahmut Terci, PhD
}

Beder University, Tirane

mterci@beder.edu.al

Doi:10.5901/ajis.2015.v4n1s1p105

\begin{abstract}
Although 'Mr. Gradgrind' and 'Mr. Bounderby' have higher class status in Hard Times, Dickens ironically describe them as 'honorable' gentlemen who cause immense destruction both in educational and economical institutions. On the one hand, as a politician and a father 'Mr. Gradgrind' grinds or destroys his children as well as other kids' imagination and sense of wondering in their learning process at home and school. Mr. Gradgrind regrets a lot in the end when he sees what he has corrupted in the nature of his children. While the children are educated with facts only, their feelings, imaginations and natural wonderings are neglected consciously. On the other hand, as a social climber, wealthy 'Mr. Bounderby' who always boasts his self-made richness, behaves unfaithfully to his mother - who always deserves respect and close care from their own children-. He also humiliates his 'hands' or workers and squeezes them as much as he can. While the workers work hard to survive, their practical, individual and social needs are not only unseen but they are also considered nonsense by their ill-mannered, dishonorable and unscrupulous boss named Mr. 'Bounderby' by Dickens. Although Hard Times is one of the shortest novels of Dickens, he makes, through it, a great difference and contribution to the society by warning the people with the descriptions of the devious gentleman. Dickens also implies that the destruction of this type of gentlemen and their effects might be sensed rather deeply in the society if they were selfish, dishonorable, dishonest politicians and wealthy people who work together. Dickens is one of the rare writers who highlight this collision, corruption, nepotism or economical and social destruction organized by them. Thus, he did not have enough time to see how these "honorable" gentlemen - mainly politicians and the rich - develop their gang with the gentleman in the media, bureaucracy and even in the military forces. If he had lived more, he would have seen how the wars, rows, struggles, conflicts, the anarchy and terrorism - artificially created by them - destroyed the millions of lives and how a lot of countries suffered from their systematic corruption and destruction.
\end{abstract}

Keywords: gentleman, Charles Dickens, Hard Times, true gentleman, devious gentleman, crime, education, Utilitarianism

\section{Introduction}

"The concept of the gentleman" in English culture was a social force from the early ages to the nineteenth century. Its great influence felt deeply especially in the Victorian society. Because even a simple term like 'the book' has varied images in everybody's mind, it is quite natural that the vague term 'gentleman' should "have different meanings in different mouths and even the same person would use it in different senses, cover[ing] interpretations of a thousand shades." (Berberich, 4) There have been varied considerations whether it has lost its social force in the modern world or its morality still exists even in the modern and/or post-modern world. A clear portrait of the gentleman can be obtained when these works - namely Robin Gilmour's The Idea of the Gentleman in the Victorian Novel (1981), Philip Mason's The Rise and Fall of the English Gentleman (1982), Philip David Castronovo's The English Gentleman: Images and Ideals in Literature and Society (1987), Shirley Robin Letwin's The Gentleman in Trollope: Individuality and Moral Conduct (1997) and Chiristine Berberich's The Image of the English Gentleman in Twentieth-Century Literature: Englishness and Nostalgia (2007) - are investigated. Thus, distinct views of critics, writers, philosophers and important figures on the concept of the 'gentleman' find their places in these works.

Not only in the mentioned works above but also in other academic works we have traced the image of the gentleman in English Culture. We have observed that the changes in the English society in their cultural and moral environment have had the most important impacts on the concept of the gentleman. The complex mixture of qualities expected in a gentleman such as his 'birthright', 'education', 'wealth', 'income', 'vocation', 'civic responsibilities' and 
'personal virtue' have made it difficult to pinpoint the exact definition. ${ }^{1}$ Although it has been hard for everybody to get an exact definition of the term because of its relation with 'masculinity', 'social class', 'manners', 'morality' and 'Englishness' we have introduced distinct views of critics, writers and important figures to observe their point of views. We have seen that the gentleman's social position in the English gentry and his evolution from the fifteenth to the nineteenth century. While the gentleman's chivalric qualities used to play important roles as well as his social status and wealth in the fifteenth and sixteenth centuries, the gentleman's manners and morals gained more importance in the subsequent centuries. Moreover, the Victorian age was the high time when gentlemanliness was in its rise and was considered almost a religion due to its popularity. The historian Penelope J. Corfield's research, The Rivals: Landed and Other Gentlemen (1996), has made it obvious that the term 'gentleman' has both social and moral connotations throughout the ages. (Corfield, 5) The important point that "the concept of the gentleman was not merely a social or class designation but there was also a moral component inherent in the concept" (Cody, 1) has also been emphasized by David Cody.

We prefer to analyze the gentleman in three main categories - namely 'gentleman of birth,', 'gentleman of wealth' and 'gentleman of manners' - according to their significant characteristics in its evolution from past to present. While the 'gentleman of birth' has been attached to 'nobility', social status as well as to chivalric characters especially in the fourteenth, fifteenth and sixteenth centuries, 'the gentleman of wealth' has been connected with his rise to upper-class through marriages or with the money he gained from wars, land or trade in the seventeenth, eighteenth and even nineteenth centuries. The idea of the gentleman has its roots in the term itself as it denotes noble birth and being wellbred. Although the 'noble birth' or 'man of ancestry' approach to the idea of gentleman was criticized by some critics, writers used to feel proud of their ancestors' 'nobility' from which they could not detach themselves too easily. In some of Dickens's works this notion can be observed. We have also seen that not only the gentleman's 'noble birth' but his 'wealth' - gained on the battlefields in the early periods mostly through trade and high rank professionals in the British colonies - also played crucial roles in his obtaining a social status in the traditional English gentry.

The nineteenth century, particularly in the Victorian England, saw the rise of the gentleman in two specific ways: first in quantity and then in quality. The increased opportunities in the social status in terms of 'wealth' and 'high rank' for the lower and middle classes caused a lot of commoners to gain a higher status in the English society. With the expansion of the British Empire the upper class needed to share the gentlemanly status with more 'ruling class' gentleman. The 'wealthy' gentleman was never rejected; he was easily accepted and welcomed to the upper class. The education of the new apprentice gentleman was a must in two aspects: his manners and intellectual capacity had to be improved. The new 'educated' or 'leveled up' gentleman in his manners, morals and mind power had significant contributions to the English society in two aspects. The integration of the gentleman in his new environment had deep impacts on preventing the bloody revolution in Great Britain - as it happened in France due to the huge gaps in life standards and the hatred between the upper and lower classes. The educated gentleman functioned like a seed in many fields of life from the rapid development in sciences, technology and industry to his engagement in political arena. His influence was felt even from the reduction of the crimes to the philosophical and sociological developments in Victorian England.

As a result of the development especially in social sciences with the incredible increase in the number of the readers who bought newspapers, periodicals, and magazines regularly, there used to be heated discussions on defining the characteristics of the gentleman. Significantly, in Victorian England, almost every intellectual approached the idea of the gentleman from various perspectives and it was time that the morality of the gentleman should gain more importance than his wealth or high status in the traditional hierarchy. There was a significant tendency to perceive and describe the gentleman with his 'gentility', 'courtesy' and gentle 'manners'. Nevertheless, it became hard to distinguish the true gentleman from snobs and devious gentlemen. That is why we have aimed at having a close look at the distinctive characteristics which made a man a true or a devious gentleman particularly in the Victorian novels. While the true gentleman, playing his role as a leader, a social reformist, a benevolent humanist, a real peacemaker, an activist and a hero dedicates his own life to his people's pleasure, happiness, comfort and welfare, the devious gentleman is selfish, never cares about the others and hurts the people he lives by. Hence, in this article Mr. Gradgrind's and Mr. Bounderby's behaviors have been investigated as the result of the destruction they cause both in the society and in the environment. With Hard Times Dickens particularly attacks both on the education system named 'Utilitarian Ideology', which neglected children's imagination, and on 'Industrialism', which neglected the workers' social needs in the portrayal of these two

${ }^{1}$ For details see Mark C. Nitcholas. The Evolution of Gentility in Eighteenth-Century England and Colonial Virginia Texas: University of North Texas, 2000. 
devious gentlemen have also been projected.

\section{2. "Grand-Grinders" in the Utilitarianism System}

The 'utilitarianism' was one of the important tendencies in Victorian Age that Dickens needed to satirize the movement when it became an obsession to 'build-up' new 'intellectual' and 'educated' individuals for the needs of the expanding empire. Not only so many unnecessary 'facts' which were aimed to be loaded into the minds of 'children' but their 'fancies' or in other words their 'imaginations' as well as their 'feelings' and 'wisdom of heart' - psychological needs were ignored so that Dickens needed to criticize the awful situation using his satirical style with this novel. Dickens also implies that the young brains are 'grinded' with the philosophy of 'utilitarianism' with the word 'grind'. As to Mr. Bounderby, the young bodies are grinded with the hard conditions - as a result of low salaries and poor social and living conditions in the factories of industrial towns.

Dickens gives special care to naming the characters that have significant meanings. In the name 'gradgrind', the word 'grind' implies the philosophy of Mr. Grandgrind's way of education which the 'facts' are the only things children should learn and unfortunately it destroys or 'grinds' the natural abilities, talents or capacities of the children. According to Grandgrind, who strictly believes that the education of 'mind' is enough, the education of the 'heart' has no importance in a person's intellectual, emotional and psychological education. Mr. Grandgrind advises his own children, Louisa and Tom, not to wonder at anything at all and what he wants them to do is to learn only about 'facts' of life. It is Dickens's way of mocking at the fashionable current in education at the time, utilitarianism.

'Now, what I want is, Facts. Teach these boys and girls nothing but Facts. Facts alone are wanted in life. Plant nothing else, and root out everything else. You can only form the minds of reasoning animals upon Facts: nothing else will ever be of any service to them. This is the principle on which I bring up my own children, and this is the principle on which I bring up these children. Stick to Facts, sir!' (Hard Times, 1)

To Mr. Gradgrind - or 'grand grinder' - who sees the human being as 'a reasoning animal', the 'facts' must be planted in the mind of the children to harvest practicality and materialism when they grow up. He believes that this is the best education style or the best way of bringing up young brains. Dickens points out how Mr. Gradgrind devotes his life to the 'education of the reason' to his family as follows:

I have systematically devoted myself (as you know) to the education of the reason of my family. The reason is (as you know) the only faculty to which education should be addressed. (Hard Times, 16)

What is wrong in his way of education is the fact that human beings are not 'reasoning animals', but in fact they are the ones who need psychological, emotional and pedagogical support beside the natural facts, laws, formulae, and the 'truths' they learn in social and physical sciences. Dickens serializes this novel, Hard Times, in Household Words to give a special emphasis on 'fancy' in a child's education. He satirizes the people like Mr. Gradgrind, who neglect the education of their children's outstanding imagination, fantastic wondering, excellent questioning and criticizing minds. In his analysis of Household Words, Paul Davis quotes Dickens's introduction of the major aim of the periodical, to encourage the "light of Fancy", in its first issue:

"No realities, will give a harsh tone to our Household Words... We would tenderly cherish that light of Fancy which is inherent in the human breast; which, according to its nurture, burns with an inspiring flame, or sinks into a sullen glare, but which (or woe betide that day!) can never be extinguishes." (Davis, 152)

The titles that Dickens chooses for the episodes - 'sowing', 'reaping' and 'garnering' - and especially the second chapter's title - 'Murdering the Innocents' - are really remarkable in terms of the education given to the children in Mr. Gradgrind's school. The name of the teacher - Mr. M'Choakumchild - at this school, or factory of twisting minds, also implies that he chokes all the children with the immense and unnecessary information that children will not use at all in their daily lives. Dickens explains the details of the unnecessary knowledge and futile information which teachers were obliged to make their children learn as in the following:

He and some one hundred and forty other schoolmasters, had been lately turned at the same time, in the same factory, on the same principles, like so many pianoforte legs. He had been put through an immense variety of paces, and had answered volumes of head-breaking questions. Orthography, etymology, syntax, and prosody, biography, astronomy, geography, and general cosmography, the sciences of compound proportion, algebra, land-surveying and 
levelling, vocal music, and drawing from models, were all at the ends of his ten chilled fingers. He had worked his stony way into Her Majesty's most Honourable Privy Council's Schedule B, and had taken the bloom off the higher branches of mathematics and physical science, French, German, Latin, and Greek. He knew all about all the Water Sheds of all the world (whatever they are), and all the histories of all the peoples, and all the names of all the rivers and mountains, and all the productions, manners, and customs of all the countries, and all their boundaries and bearings on the two and thirty points of the compass. Ah, rather overdone, M'Choakumchild. If he had only learnt a little less, how infinitely better he might have taught much more! (Hard Times, 7)

Dickens criticizes not only the education system in the Victorian age but also the mentality of the schoolmasters who aim at teaching the 'facts' only and neglect the children's feelings, imagination and their 'wisdom of the heart'. With the word 'all', Dickens also gives a special emphasis on how hard it would be for children to learn all the things their teachers intended to put in their minds. Their abilities in art, music or writing related to their 'wonderful' imagination have always been ignored. Although many years have passed since the publication of the novel, Dickens's criticism of the system of education is still fresh. There are a lot of teachers today who neglect children's special abilities in various domains - especially in art, music, literature, acting, management, economy, leadership, and ...etc. - They get stuck to teach certain 'facts' in the school curriculum. Instead of guiding and helping them to improve their special abilities, certain 'school subjects' are forced to be taught. Although for many ordinary people colors, fish, dogs and kites are just the simple things that cannot draw their attention, for some children they might mean a lot due to their wonderful effects in their extraordinary imagination. It looks, thus, as if utilitarianism is still vivid in many education systems in Europe today.

When Dickens's model students, Louisa and Tom, are caught by Mr. Gradgrind in a group of children who have been 'wondering' and trying to see what is going on in the circus nearby the school, their reply - which is 'we wanted to see what it was like..'- shocks him as:

'You! Thomas and you, to whom the circle of the sciences is open; Thomas and you, who may be said to be replete with facts; Thomas and you, who have been trained to mathematical exactness; Thomas and you, here!' cried Mr. Gradgrind. (Hard Times, 11)

As a result, Louisa and Tom are sent back home. The 'facts' are taught in a much disciplined way. At home and at school their imagination and questioning mind cannot find a path to proceed. Obviously, not only their questions about life, but also their own abilities and own desires are also ignored. Or in other words, their hidden abilities or 'treasures' are left to die down by the school system which has been promoted in those times. Louisa's conclusion to all this, that she is "tired of everything" comes as no surprise.

'I was tired, father. I have been tired a long time,' said Louisa.

'Tired? Of what?' asked the astonished father.

'I don't know of what - of everything, I think.' (Hard Times, 11)

Due to the negative effects of the Mr. Gradgrind's method of teaching, Louisa and Tom get tired and sick of everything. They start to hate whatever surrounds them. Like machines, they do not feel any joy or enthusiasm in life. Psychologically challenged and pedagogically neglected children, similar to Louisa and Tom, might tend to cut off not only their interest in learning, but also their relationship with their parents, brothers and friends. They might feel stupid and lonely. Tired of being called 'stupid', 'lazy' and 'idiot', they might sulk in a corner and tend to cut off all their connections with life. Then, they might start to reject any new method which is tried on them. Similar behaviors are portrayed by Dickens. Tom, for example, says that "he hates everything except Louisa" and feels like a "donkey" or a "mule". (Hard Times, 45-46) He also promises to take revenge on the things and the people that have compelled him to learn:

'I wish I could collect all the Facts we hear so much about,' said Tom, spitefully setting his teeth, 'and all the Figures, and all the people who found them out: and I wish I could put a thousand barrels of gunpowder under them, and blow them all up together! However, when I go to live with old Bounderby, I'll have my revenge.' (Hard Times, 46)

Dickens believes that to give an education to children, as Mr. Gradgrind does, is similar to murder them so that he entitles the first chapter 'Murdering the Innocents'. In another incident when Louisa and Tom have a conversation, they are interrupted by Mr. Gradgrind to be warned not to wonder anymore. Dickens describes the scene and gives some clues of his own thoughts about the education system.

When she was half a dozen years younger, Louisa had been overheard to begin a conversation with her brother 
one day, by saying 'Tom, I wonder' - upon which Mr. Gradgrind, who was the person overhearing, stepped forth into the light and said, 'Louisa, never wonder!'

Herein lay the spring of the mechanical art and mystery of educating the reason without stooping to the cultivation of the sentiments and affections. Never wonder. By means of addition, subtraction, multiplication, and division, settle everything somehow, and never wonder. Bring to me, says M'Choakumchild, yonder baby just able to walk, and I will engage that it shall never wonder. (Hard Times, 43)

Showing that this kind of method makes children hate the sciences, Dickens implies that better methods which never neglect children's imagination, fancies, desires and special talents should be seriously considered in education. According to Dickens, children's imagination should not be ignored and with a special guidance their 'minds' and 'hearts' should be cared for and enriched. Children are not mechanical objects and unnecessary 'facts' and 'figures' should not be taught by force. Ignoring what exactly children need and neglecting their own capacities and abilities will cause serious problems sooner or later. The fact that every child is special should be transmitted to all children. What great personalities like Edison, Einstein, Leonardo de Vinci and Agatha Christie have in common is the fact that they imagined, thought and wondered in a different, critical and extraordinary way so that their contribution to humanity was greater than that of others.

A specific 'non-fictional' example should probably be mentioned here. In The Freedom Writers Diary (1999), written by the English teacher Erin Gruwel with her one hundred fifty students in Long Beach, California, she describes how the students attempt to change themselves as well as the world around through writing. Gruwell's students used to have many criminal problems as well as no respect and no tolerance to each other due to their backgrounds, but she pursues education beyond high school. She encourages her students, who used to go home, to use gunfire, drugs, be part of gangs or in a host of other difficult situations, to read and write. After hard times, instead of being involved in serious crime her students started to get rid of their bad habits, tried hard to be away from criminal issues, made peace with other classmates from different cultural backgrounds and, more importantly, they believed that by writing they can change themselves and the world and contribute to the welfare of the society. Unfortunately, Louisa and Tom never met such a special teacher like Erin Gruwel during their school education. However, Sissy, or Cecilia Jupe, whose personality is improved by her parents and whose imagination is evoked by the people working in the circus, is chosen by Dickens to be a true model for free life. Sissy is also his model fictitious child in the novel who innocently attacks Gradgrind's mentality and his utilitarianism. When she is satirically asked about the 'horses on the wall' and the 'flowers on the carpet', she innocently replies that she would fancy or imagine "the walls papered with horses on it" and "the flowers pictured on the carpets". (HT, 6) But, Sissy's teacher and Mr. Gradgrind warn her not to allow fancy cover facts:

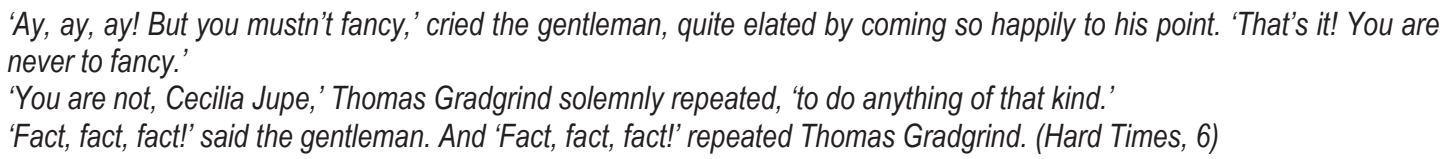

Sissy also explains to Louisa that her father has been a 'clown', who used to amuse the spectators, and that she used to read funny stories to her father. Story books or novels have been the kind of books which are forbidden for Louisa and Tom as they have been considered not to be able to exactly state the 'facts'. The characters, plots or places might be imaginary in fiction, but, in fact, they actually illustrate what writers observe from the real life. Whatever is portrayed or described in literary works, they have all some relations to some extent with real life. During her stay with the Gradgrinds, she innocently evokes, induces or inspires the notions of 'love', 'respect', 'kindness' 'and 'sincerity', which are mainly related to the wisdom of heart, to the people around her - mostly to Louisa -. Mr. Gradgrind also feels that she has a quality which is really different:

Somehow or other, he had become possessed by an idea that there was something in this girl which could hardly be set forth in a tabular form. (Hard Times, 82)

Sissy becomes an indispensable person for the Gradgrinds. Mr. Gradgrind thinks that Sissy really comforts her dear daughter and that's why he has permitted her long stay at his home even though she has hardly been successful in mathematics, statistical calculations or defining terms. 


\section{3. "Honorable", Deaf, Dumb, Blind, Lame, and Dead Gentleman}

In the meantime, the innocent personalities are murdered by the 'Grinders' at home and by the 'Chokers' at school who apply their cruel philosophy to them. On the contrary, Mr. Sleary destroys their philosophy with their product, Sissy. Dickens implies this with the choice of the name, Sleary, a person who is a 'sleer or slayer', meaning a 'killer', a 'destroyer' or a 'murderer'. While the educational system of Mr. Gradgrind grinds children in their mills, Mr. Sleary attacks and destroys their philosophy. Sleary believes that:

...People mutht be amuthed, Thquire, thomehow, ' continued Sleary, rendered more pursy than ever, by so much talking; 'they can't be alwayth a working, nor yet they can't be alwayth a learning. Make the betht of uth; not the wurtht. l've got my living out of the horthe-riding all my life, I know; but I conthider that I lay down the philothophy of the thubject when I thay to you, Thquire, make the betht of uth: not the wurtht!' (Hard Times, 36-37)

According to Mr. Sleary, people are not machines; they need to be entertained, they need to be amused; they need a break to rest because they cannot always work and learn endlessly. More importantly, their needs after hard work or exhausting study should be felt by parents and teachers so that their psychological needs and feelings should not be ignored. If this fact about human beings were understood by the squires - as Mr. Sleary calls them - or the gentlemen who design and settle the system for education and economy, they would do their best. Otherwise, they would cause great destructions in the lives of innocent people, especially of students and workers. In this novel, these gentlemen are described by Dickens as follows:

...Time hustled him into a little noisy and rather dirty machinery, in a by-comer, and made him Member of Parliament for
Coketown: one of the respected members for ounce weights and measures, one of the representatives of the
multiplication table, one of the deaf honourable gentlemen, dumb honourable gentlemen, blind honourable gentlemen,
lame honourable gentlemen, dead honourable gentlemen, to every other consideration. (Hard Times, 82)

Dickens satirizes the members of the parliament in reference to Mr. Gradgrind for the laws they pass especially related to education and economy. These 'honorable gentlemen' are described as deaf and blind because they never listen to or see the problems of the people they represent. By chance, even if they hear their problems, they never have the capacity to apprehend or they are unable to explain their problems because they are dumb. They are also lame in their receptive skills and perspectives so that whatever ideas they produce, they are born dead.

Mr. Gradgrind's children and Mr. M'Choakumchild's students - Louisa and Tom -, who have been produced in such a factory with their philosophy, cannot overcome the difficulties of they encounter in real life. Their lives are ruined by Mr. Gradgrind's 'factual' decisions and his teachings. Louisa's life is deeply ruined when she is forced to marry Mr. Bounderby, whom she really hates. When Mr. Gradgrind tries to convince his daughter to marry an elderly gentleman the arguments he puts forward contrast with the facts in terms of reason and calculation. She might have insisted on not accepting this unreasonable proposal, but instead she accepts it unwillingly implying that "the life is very short and she has no other choice" (Hard Times, 89) due to her physical, psychological and pedagogical imprisonment. Louisa reminds these facts to her father:

'Father,' she returned, almost scornfully, 'what other proposal can have been made to me? Whom have I seen? Where have I been? What are my heart's experiences?'

'My dear Louisa,' returned Mr. Gradgrind, reassured and satisfied. 'You correct me justly. I merely wished to discharge my duty.'

'What do I know, father,' said Louisa in her quiet manner, 'of tastes and fancies; of aspirations and affections; of all that part of my nature in which such light things might have been nourished? (Hard Times, 90)

Louisa points out the weak sides of her nature as a result of her father's stickiness to 'facts' and 'figures' and to the focus on the education of the mind. Her tastes, fancies, aspirations and affections have been ignored because they have been considered not only useless but also harmful. They might have feared that these qualities could be obstacles for them during the learning process. Furthermore, according to these gentlemen, like Mr. Gradgrind, the model students or people must ignore this kind of useless feelings and ideas; facts must be learned; then they must be applied in their daily life; they must behave accordingly so that they become factual models in the society.

Louisa becomes Mrs. Bounderby after the marriage for the sake of her brother, Tom, whom she really cares for., and who is given a job for his sister's sake at Mr. Bounderby's factory. This fact is noticed by the gentleman - Mr. Harthouse - during his first visit. When Tom enters the room and joins for the meal, her cold manners change, her 
gloomy face brightens up with a beaming smile and he notices a lovely light - which represents her love and care for him - in her eyes.

'Is there nothing,' he thought, glancing at her as she sat at the head of the table, where her youthful figure, small and slight, but very graceful, looked as pretty as it looked misplaced; 'is there nothing that will move that face?'

Yes! By Jupiter, there was something, and here it was, in an unexpected shape. Tom appeared. She changed as the door opened, and broke into a beaming smile.

A beautiful smile. Mr. James Harthouse might not have thought so much of it, but that he had wondered so long at her impassive face. (Hard Times, 117)

Tom's snobbish character, drinking and gambling drags him into an extravagant lifestyle. Not only does he waste his own salary, but he never uses the extra money he gets from Louisa to pay his debts so he starts making plans to steal money from Mr. Bounderby's bank. Meanwhile, Mr. Harthouse gets more information about Louisa and he finds out her weakest point which is the fact that she hates her husband. He also learns that Louisa married Mr. Bounderby just for the sake of her brother. Using Louisa's secret, Mr. Harthouse tries to be closer to her. But in fact, it is just a new sensation. Dickens writes that what exactly he looks for is not real love, but a sensation he will be occupied with or an engagement he will spend his time with.

Mr. James Harthouse began to think it would be a new sensation, if the face which hanged so beautifully for the whelp, would change for him. (Hard Times, 150)

Dickens also describes his nature with his own words in a conversation with Louisa. Mr. Harthouse says that:

'Mrs. Bounderby, no: you know I make no pretence with you. You know I am a sordid piece of human nature, ready to sell myself at any time for any reasonable sum, and altogether incapable of any Arcadian proceeding whatever.' (Hard Times, 152)

However, Mr. Harthouse establishes a confidence with her, artfully excluding her husband. As Dickens writes that "he had artfully, but plainly, assured her that he knew her heart in its last most delicate recesses; he had come so near to her through his tenderest sentiment; he had associated himself with that feeling; and the barrier behind which she lived, had melted away." (157) They start to meet secretly. When they have been noticed and caught in a very private conversation by Mrs. Sparsit, who is Mr. Bounderby's clerk in the bank, she informs Mr. Bounderby about this immediately, implying that Louisa would elude with Mr. Harthouse, hoping for a kind of a reward or at least a compliment for her deed. Instead of a compliment she receives curses from Mr. Bounderby. Luisa never lets her relationship go further with Mr. Harthouse. She decides neither to continue her marriage with Mr. Bounderby, nor to elope with Mr. Harthouse, as she is extremely confused what to do in a matter of love. Mr. Harthouse finds himself in a very ridiculous situation when he is easily convinced by Sissy to leave the town, giving him a message that Louisa has no intention to see or speak with him anymore. He is shocked as he has never expected to get a reply from Louisa. Actually, he has not been so serious in this matter so that he decides to leave the town instead of insisting to find a way to communicate with Louisa.

Louisa bursts out to her father at home and criticizes him painfully with tears in her eyes. While crying she points out how awfully she has been brought up and asks him:

'How could you give me life, and take from me all the inappreciable things that raise it from the state of conscious death? Where are the graces of my soul? Where are the sentiments of my heart? What have you done, 0 father, what have you done, with the garden that should have bloomed once, in this great wilderness here!' (Hard Times, 193)

Mr. Gradgrind realizes his great mistake when Louisa falls on her feet and bitterly points out the fact that his philosophies of life and teachings have been useless to her. He is the one who has been responsible for improper education and the unreasonable marriage and he has consciously neglected her heart in these important cases. When he sees her collapsing at his feet, he really regrets how awful he has been to her in terms of his teachings. The scene also implies the collapse of his philosophy and his teaching. Dickens points out these facts in the novel as follows:

All that I know is, your philosophy and your teaching will not save me. Now, father, you have brought me to this. Save me by some other means!'

He tightened his hold in time to prevent her sinking on the floor, but is she cried out in a terrible voice, 'I shall die if you 
hold me! Let me fall upon the ground!' And he laid her down there, and saw the pride of his heart and the triumph of his system, lying, an insensible heap, at his feet. (Hard Times, 196)

Mr. Gradgrind's second model child, Tom, ruins not only his own life because of his addiction to gambling, but he also destroys Stephan Blackpool's life by laying on him the blame of his theft. In his plan, Tom makes Mr. Blackpool appear around the bank a few days before he leaves the town. In fact, Blackpool has just been an innocent worker at Mr. Bounderby's factory who is fired by Mr. Bounderby when he cannot be convinced to break the strike against his friends although he does not share the method of his friends to get pay rise for their work. Everybody suspects Mr. Blackpool for the theft, but in the end it is figured out that Tom has stolen the money and has made Mr. Blackpool behave so in order to cast suspicion on him. Mr. Gradgrind agrees to make plans to send Tom abroad with the help of Sissy and Mr. Sleary. Just before Tom escapes from Coketown, Bitzer appears in the scene and attempts to spoil their plan. Because Bitzer has got his education at Mr. Gradgrind's school his questions or comments such as: "have you a heart?", "is it accessible to any compassionate influence?", "what motive can you have for preventing the escape of this wretched young and crushing his miserable father?", "See his sister here. Pity us!" do not make any sense to him unless he is promised to be rewarded with a sum of money as he believes that "the whole social system is a question of self-interest." (Hard Times, 257)

As for Mr. Bounderby, he is a rich man and a very close friend of Mr. Gradgrind's although he is quite different from him in his behavior - especially in his rude and unkind manners -. He enjoys talking about his hard times in the past and boasts his self-made richness with his determination. He exaggerates the poor conditions he used to suffer. Dickens describes Mr. Bounderby's appearance and character as:

\begin{abstract}
He was a rich man: banker, merchant, manufacturer, and what not. A big, loud man, with a stare, and a metallic laugh. A man made out of a coarse material, which seemed to have been stretched to make so much of him. A man with a great puffed head and forehead, swelled veins in his temples, and such a strained skin to his face that it seemed to hold his eyes open, and lift his eyebrows up. A man with a pervading appearance on him of being inflated like a balloon, and ready to start. A man who could never sufficiently vaunt himself a self-made man. A man who was always proclaiming, through that brassy speaking-trumpet of a voice of his, his old ignorance and his old poverty. A man who was the Bully of humility. (HT, 12)
\end{abstract}

His 'vaunting' with his self-made recent position and his endless 'boasting' about his old ignorance and poverty makes him a kind 'bully' who is not ashamed of showing off. However, a true gentleman is supposed to be humble and modest about his accomplishments or successes. Dickens points out his unkind and ill-mannered character, due to his ignorance and his rejection of his real past. Another important fact about this character is his unkind behavior towards his modest mother. Dickens keeps the secret of Mrs. Pegler, but by the end of the novel, his unfaithfulness to his mother is discovered by everybody. Mr. Bounderby, who denies his past, never gets ashamed to tell lies and always brags. He becomes rich most probably in illegal ways -Dickens implies collusion and nepotism in close relationship with the honorable gentlemen in the parliament-, and destroys the ecological system of the town with the smoke and sewage from his factories as well as the workers' lives with hard work, small wages and monotonous lifestyle, compared by Dickens with the machines used in the factory. Mr Bounderby may thus be the twin brother of the (most) devious and harmful gentleman in the novel, Mr. Gradgrind. Mr. Bounderby and Mr. Gradgrind work collaboratively in the ruining of the lively creatures in the world; while Bounderby destroys the ecological system of the town, the workers' lives and the economy of the country, Mr Gradgrind ruins the society by bringing up self-interested human beings whose hearts and imagination are ignored systematically with an unrealistic education system which is passed in the parliament by Gradgrind-like honorable gentlemen. While Louisa and Tom are the artistic productions of Mr. Gradgrind, Coketown is the masterpiece of Mr. Bounderby.

Coketown, where the story takes place and which is shaped according to the philosophy of these "honorable" gentlemen, is described by Dickens as follows:

It was a town of red brick or of brick that would have been red if the smoke and ashes had allowed it; but as matters stood, it was a town of unnatural red and black like the painted face of a savage. It was a town of machinery and tall chimneys, out of which interminable serpents of smoke trailed themselves for ever and ever, and never got uncoiled. It had a black canal in it, and a river that ran purple with ill-smelling dye, and vast piles of building full of windows where there was a rattling and a trembling all day long, and where the piston of the steam-engine worked monotonously up and down, like the head of an elephant in a state of melancholy madness. It contained several large streets all very like one another, and many small streets still more like one another, inhabited by people equally like one another, who all went in and out at the same hours, with the same sound upon the same pavements, to do the same work, and to whom every day 
was the same as yesterday and to-morrow, and every year the counterpart of the last and the next. (Hard Times, 19)

What these devious as the opposite meaning of "honorable" gentlemen manage to do is just blackening and destroying their surroundings. Blackened towns, mechanized dwellers and dummied young brains are just some of their "admirable great works of art'. Dickens successfully portrays not only the gloomy atmosphere in the town with 'smoke', 'black canal', 'purple river with ill-smelling dye', but also the extremely boring lifestyle which the workers or dwellers are obliged to endure the monotonous life here.

Mr. Bounderby's shameful lie, what he has said about his mother, is uncovered. He used to say that he was born in a ditch, was abandoned and used to call his mother the worst woman that ever lived in the world. When his mother, Mrs. Pegler, is brought up to his office by Mrs. Sparsit's, as a result of her suspicious presence around the bank and is accused of the bank robbery, she tells the whole truth about him and herself. It is revealed that Mr. Bounderby has been misinforming everybody with his disgusting lies for a long time and, worse than that, instead of taking close care of his own humble mother, he pretends to have no mother according to the agreement which she has been obliged to respect. Since she is the mother and has a mother's heart, she has been content to see her only son secretly from a distance once a year. Even though, she spends all the money she could save in a year, she never hesitates to spend it just to see her son for a very short time. Mrs. Pegler states the truth as follows:

\begin{abstract}
'And my dear boy knows, and will give you to know, sir, that after his beloved father died, when he was eight years old, his mother, too, could pinch a bit, as it was her duty and her pleasure and her pride to do it, to help him out in life, and put him 'prentice. And a steady lad he was, and a kind master he had to lend him a hand, and well he worked his own way forward to be rich and thriving. And l'll give you to know, sir - for this my dear boy won't - that though his mother kept but a little village shop, he never forgot her, but pensioned me on thirty pound a year - more than I want, for I put by out of it only making the condition that I was to keep down in my own part, and make no boasts about him, and not trouble him. And I never have, except with looking at him once a year, when he has never knowed it. And it's right,' said poor old Mrs. Pegler, in affectionate championship, 'that I should keep down in my own part, and I have no doubts that if I was here I should do a many unbefitting things, and I am well contented, and I can keep my pride in my Josiah to myself, and I can love for love's own sake! And I am ashamed of you, sir,' said Mrs. Pegler, lastly, 'for your slanders and suspicions. And I never stood here before, nor never wanted to stand here when my dear son said no. And I shouldn't be here now, if it hadn't been for being brought here. And for shame upon you, Oh, for shame, to accuse me of being a bad mother to my son, with my son standing here to tell you so different!' (Hard Times, 234-235)
\end{abstract}

Pretending as if nothing had happened, Mr. Bounderby sees off everybody without any explanation and rudely says that he is not bound to deliver a lecture on his family affairs. Mr. Bounderby's reputation of being a sincere, honorable gentleman is destroyed by his own mother. Dickens reveals his lies about his family, yet he leaves unveiled the way in which Bounderby has raised his money. Such devious gentlemen, who usually prefer working with the 'honorable gentlemen' in the parliament, raise their money in unknown ways. Not only had the neglect of the workers' welfare, but also the pollution of the environment affected the lives of the people in Coketown. Dickens criticizes the negative effects of the 'industrial revolution' by creating the particular word 'Coketown' and by clearly implying that the whole 'town' smells 'coke' vaporized from the 'chimneys' as a result of the consumption of 'coal' in the factories.

\title{
4. Conclusion
}

With Hard Times, Dickens portrays how innocent lives are destroyed in a sullen system set up by devious gentlemen. Although Dickens is criticized for his 'sullen socialism' with this novel by critics like Thomas Babington Macaulay (Davis, 153), he combines the innocent social groups, such as children and workers who used to be treated badly or whose 'natural' needs used to be neglected consciously during their life time. The grinding system at home, school and work which neglects children's imagination and people's social welfare and makes them spiritless robot-like-individuals has negative impacts on the social life as well as on the natural life. The destruction starts in the minds and then it reaches anywhere where anybody lives like an infectious disease or a deadly virus which spreads rapidly anywhere. Wicked and devious gentlemen play important roles in such mass destructions. Dickens warned the Victorians in his lifetime with works like Hard Times and, to some extent, he is continually warning the individuals and giving his invaluable messages about the villains disguised as gentlemen in real life. 


\section{Primary Resource}

Dickens, Charles. (Hard Times (1854), London: Penguin Books. 1994.

\section{Secondary Resources}

Berberich, Christine. (2007). The Image of the English Gentleman in Twentieth-Century Literature: Englishness and Nostalgia. Cornwall: Ashgate Publishing Company.

Corfield, Penelope J. (1996). The Rivals: Landed and Other Gentlemen. Retrieved from N.B. Harte and R. Quinault (eds) Land and Society in Britain, 1700-1914 (Manchester, 1996), pp. 1-33.

Davis, Paul. Critical Companion to Charles Dickens,(A Literary Reference to His life and Work), New York: Facts On File, 2007.

Nitcholas, Mark. C. The Evolution of Gentility in Eighteenth-Century England and Colonial Virginia, Texas: University of North Texas, 2000.

Internet Resources

David Cody, The Gentleman, http://www.victorianweb.org/history/gentleman.html, retrieved April 12, 2009 